ISSN : 2303-1514 | E-ISSN : 2598-5949

DOI : http://dx.doi.org/10.33578/jpfkip.v10i3.8293

https://primary.ejournal.unri.ac.id/index.php/JPFKIP

\title{
RELIGIOUS ORIENTATION AS THE HIDDEN CURRICULUM IN THE LEARNING PROCESS DURING THE COVID-19 PANDEMIC
}

\author{
Mirza Basyiruddin ${ }^{1}$, Rukayah $^{2}$, Roemintoyo $^{3}$ \\ 1,2,3 Universitas Sebelas Maret, Surakarta, Indonesia. \\ Imzdrieinc@gmail.com, ${ }^{2}$ rukayah@staff.uns.ac.id, ${ }^{3}$ roemintoyo@yahoo.co.id
}

\section{ORIENTASI AGAMA SEBAGAI KURIKULUM TERSEMBUNYI PADA PROSES PEMBELAJARAN DI MASA PANDEMI COVID-19}

\begin{tabular}{|c|c|}
\hline ARTICLE HISTORY & ABSTRACT \\
\hline $\begin{array}{l}\text { Submitted: } \\
06 \text { Mei } 2021 \\
06^{s t} \text { May } 2021\end{array}$ & $\begin{array}{l}\text { Abstract: Religious orientation is a hidden curriculum that affects the process of implementing } \\
\text { education in an institution. This is evident from the existence of various religious activities held } \\
\text { at schools to instill students' religious values in order to make them religious individuals. This } \\
\text { study aimed to reveal various religious activities occured as a hidden curriculum in one of the } \\
\text { public elementary schools in Kecamatan Kalijambe, Kabupaten Sragen. } 2 \text { problems were } \\
\text { investigated in this study. The first was to reveal various religious activities and their } \\
\text { suitability with the religion professed by students. The second was to describe the process of } \\
\text { these activities before and during the Covid-19 pandemic. This study utilized a qualitative } \\
\text { approach because of the suitability of its characteristics to assess and describe the reality that } \\
\text { occured. Case study was a form of qualitative research chosen in this study since there were } \\
\text { specific problems being studied. The results showed that there were religious activities such as } \\
\text { praying before and after lessons, reciting Al-Quran, reading Asmaul Husna, scheduling dhuha } \\
\text { prayers, dhuhur prayers in congregation, kultum after dhuhur prayer, routine infaq, saying } \\
\text { greetings, and in neat uniform. These activities had undergone the implementation adjustments } \\
\text { during the covid-19 pandemic. }\end{array}$ \\
\hline
\end{tabular}

Accepted:

01 Juni 2021

$01^{\text {st }}$ juni 2021

Keywords: religious orientation, hidden curriculum, learning during the pandemic

Abstrak: Orientasi agama merupakan kurikulum tersembunyi yang mempengaruhi proses penyelenggaraan pendidikan di suatu lembaga. Hal ini terbukti dari adanya berbagai kegiatan keagamaan di sekolah yang diselenggarakan untuk dapat menanamkan nilai-nilai agama kepada peserta didik agar menjadi pribadi yang religius. Penelitian ini bertujuan untuk mengungkap berbagai kegiatan keagamaan yang terjadi sebagai kurikulum tersembunyi pada salah satu SD Negeri di Kecamatan Kalijambe Kabupaten Sragen. Terdapat 2 permasalahan yang dikaji dalam penelitian ini. Pertama yakni mengungkap berbagai kegiatan yang bersifat keagamaan yang terjadi serta kesesuaiannya dengan agama yang dianut oleh peserta didik. Kedua, mendeskripsikan proses kegiatan tersebut berlangsung sebelum dan selama pandemi covid-19. Penelitian ini menggunakan pendekatan kualitatif karena kesesuaian karakteristiknya untuk mengkaji dan mendeskripsikan realitas yang terjadi. Studi kasus merupakan bentuk penelitian kualitatif yang dipilih karena terdapat permasalahan khusus yang dikaji. Hasil penelitian menunjukkan bahwa terdapat kegiatan keagamaan berupa doa sebelum dan sesudah pelajaran, membaca Al-Quran, membaca asmaul husna, penjadwalan salat dhuha, salat dhuhur berjamaah, kultum setelah salat dhuhur, infaq rutin, mengucapkan salam, dan berseragam rapi. Kegiatan tersebut mengalami penyesuaian pelaksanaan selama pandemi covid-19 berlangsung.

Kata Kunci: orientasi agama, kurikulum tersembunyi, pembelajaran masa pandemi

\section{CITATION}

Basyiruddin, M., Rukayah, R., \& Roemintoyo, R. (2021). Religious Orientation as the Hidden Curriculum in the Learning Process during the Covid-19 Pandemic. Primary: Jurnal Pendidikan Guru Sekolah Dasar, 10 (3), 565-574. DOI: http://dx.doi.org/10.33578/jpfkip.v10i3.8293. 


\section{PENDAHULUAN}

Penyelenggaraan pendidikan tentunya memerlukan perencanaan yang baik. Perencanaan tersebut dilakukan dengan menghadirkan kurikulum yang nantinya akan berwujud berbagai kegiatan pembelajaran untuk peserta didik. Di Indonesia, kurikulum 2013 merupakan kurikulum inti yang resmi berlaku. Kurikulum 2013 merupakan standar pelaksanaan pembelajaran yang wajib dilakukan oleh lembaga pendidikan.

Kurikulum 2013 menekankan pada pendidikan karakter. Hal tersebut dikarenakan Indonesia sendiri mengalami berbagai dampak negatif adanya degradasi karakter pada diri seseorang. Berbagai permasalahan seperti korupsi, tindak kriminal, gesekan antar suku maupun umat beragama, terorisme, dsb, merupakan bukti nyata dari kurangnya penanaman karakter yang baik dan luhur. Permasalahan yang ditimbulkan akibat kurang terbentuknya karakter tersebut juga diperparah dengan paradigma masyarakat bahwa peserta didik yang cerdas itu memperoleh nilai yang baik pada mata pelajaran matematika dan Ilmu Pengetahuan Alam (IPA). Tentunya, paradigma tersebut mengutamakan kecerdasan aspek kognitif saja, sedangkan kecerdasan aspek afektif dan spiritual dikesampingkan. Paradigma berpikir tersebut harus dirubah melalui pendidikan karakter. Aisyah (2018: 13) berpendapat bahwa pendidikan karakter merupakan kegiatan yang dilakukan secara sadar dan terencana dalam memfasilitasi dan membantu peserta didik untuk mengetahui halhal yang baik dan luhur, mencintainya, memiliki kompetensi intelektual, berpenampilan menarik, dan memiliki kemauan yang keras untuk memperjuangkan kebaikan dan keluhuran serta dapat mengambil keputusan secara bijak, sehingga ia mampu memberikan kontribusi positif dalam kehidupan berbangsa dan bernegara.

Berbagai kompetensi inti termuat dalam kurikulum 2013 yang harus dicapai oleh peserta didik. Kenyataannya, peserta didik dituntut untuk menguasai kompetensi lebih dari standar kurikulum 2013. Hal tersebut terjadi karena adanya pengembangan kurikulum yang dilakukan oleh lembaga pendidikan terkait. Pengembangan kurikulum ini dilatarbelakangi adanya visi misi khusus lembaga pendidikan, otonomi pendidikan sesuai dengan karakteristik wilayahnya, tuntutan masyarakat sekitar akan pelayanan pendidikan yang diharapkan, dsb. Hamalik (2017: 188) mengungkapkan bahwa hal yang penting dicermati dalam pengembangan kurikulum ini adalah adanya hubungan, kaitan, dan saling mendukung antara tujuan yang satu dengan yang lainnya.

Salah satu wujud pengembangan kurikulum tersebut yakni adanya kurikulum tersembunyi yang dihadirkan oleh lembaga pendidikan. Setiawan (2017) berpendapat bahwa kurikulum tersembunyi merupakan pelengkap dari kurikulum resmi, bahan ajar, maupun metode pembelajaran yang telah disusun pemerintah. Noor (2012: 29) menyatakan bahwa konsep kurikulum tersembunyi terespresikan dalam gagasan bahwa sekolah melakukan lebih dari sekedar menyebarkan pengetahuan, seperti tercantum dalam kurikulum resmi. Mustaqim (2018) berpendapat cakupan kurikulum tersembunyi ini sangatlah luas, termasuk segala bentuk pendidikan, misalnya kegiatan rekreasional, kemasyarakatan, budaya, yang mengajarkan nilai-nilai pelajaran yang sebenarnya tak sengaja. Kesimpulannya, kurikulum tersembunyi merupakan berbagai kegiatan yang memberikan pengalaman belajar kepada peserta didik yang bukan merupakan bagian dari kurikulum inti atau resmi.

Kurikulum tersembunyi harus disadari keberadaannya. Caswita (2013: 49) menyatakan bahwa pihak sekolah harus bisa mengelola hidden curriculum (kurikulum tersembunyi) agar dapat bermanfaat bagi proses pendidikan anak dan menghindari pengaruh-pengaruh negatif dari adanya hidden curriculum. Kegiatan kurikulum tersembunyi oleh Nisa (2009) menyatakan banyak hal yang menjadi bagian dari hidden curriculum antara 
lain yang dapat kita lakukan adalah program pembinaan \pm 60 menit, yang terdiri dari salat zuhur berjamaah dan pembinaan spiritual \pm 45 menit yang bertujuan melakukan pembinaan terhadap siswa secara lebih personal dalam upaya membantu siswa memahami pelajaran agama dan mengamalkan akhlak mulia dalam kehidupan sehari-hari.

Pengembangan kurikulum tersembunyi harus memperhatikan pemenuhan pendidikan karakter, khususnya karakter religius. Indonesia merupakan negara yang memberikan hak kepada warganya untuk memeluk agama yang dikehendaki sesuai amanat Pancasila sila ke-1 yakni Ketuhanan Yang Maha Esa. Oleh karena itu, pemenuhan kebutuhan pendidikan keagamaan perlu diperhatikan. Rahmawati, Afifulloh, \& Sulistiono (2020) berpendapat bahwa pembentukan karakter keagamaan dilaksanakan setiap hari melalui kegiatankegiatan religius.

Orientasi agama berkaitan dengan pandangan kepercayaan terhadap Tuhannya atau pendekatan seseorang dalam memeluk sebuah agama. Indonesia merupakan negara yang memiliki ragam agama yang dianut oleh penduduknya. Tentunya, setiap agama memiliki kekhasan sendiri dalam melakukan kegiatan keagamaannya. Oleh karena itu, pelaksanaan kegiatan keagamaan harus sesuai dengan agama yang dianut oleh peserta didik.

Orientasi agama merupakan kurikulum tersembunyi karena mempengaruhi pelaksanaan kegiatan pendidikan. Hal tersebut dikarenakan orientasi agama berkaitan dengan pandangan serta pendekatan pelaksanaan kegiatan sesuai dengan kepercayaannya. Bidang sosial politik, kepercayaan, kepatuhan, pelajaran tentang nilai adat dan budaya, pegembangan sikap terhadap sesama manusia dan penguatan perbedaan kelas merupakan hasil pendidikan dari hidden curriculum atau kurikulum tersembunyi (Prasetya, Febriyanto, \& Ryanto, 2020). Orientasi agama sebagai kurikulum tersembunyi dapat dibuktikan melalui adanya berbagai sekolah berlatar keagamaan yang ada di Indonesia. Namun, sekolah yang berstatus negeripun juga terpengaruh dari adanya orientasi agama ini yang dibuktikan melalui pengembangan berbagai kegiatan keagamaan diluar kurikulum inti atau resmi. Pada penelitian ini, akan mengungkap orientasi agama sebagai kurikulum tersembunyi pada salah satu SD Negeri di Kecamatan Kalijambe Kabupaten Sragen melalui analisis kegiatan keagiatan keagamaan yang dilaksanakan saat sebelum dan selama pandemi covid-19 berlangsung.

\section{METODE PENELITIAN}

Salah satu SD Negeri di Kecamatan Kalijambe Kabupaten Sragen dipilih sebagai lokasi penelitian ini. Alasan pemilihan lokasi penelitian tersebut antara lain: peneliti memiliki hubungan yang baik dan terbuka dengan tenaga pendidik dan kependidikan dengan SD Negeri terkait, akses yang mudah dijangkau, serta sekolah tersebut belum pernah diteliti terkait kegiatan keagamaan sebagai kurikulum tersembunyinya. Penelitian ini dilakukan selama semester 1 tahun ajaran 2020-2021 pada peserta didik kelas 6 yang berjumlah 34 orang yang terdiri dari 14 peserta didik putra dan 20 peserta didik putri.

Penelitian menggunakan pendekatan kualitatif. Moleong (2018: 6) menyatakan penelitian kualitatif adalah penelitian yang bermaksud untuk memahami fenomena tentang apa yang dialami oleh subjek penelitian misalnya perilaku, persepsi, motivasi, tindakan, dll., secara holistik, dan dengan cara deskripsi dalam bentuk kata-kata dan bahasa, pada suatu konteks khusus yang alamiah dan dengan memanfaatkan berbagai metode alamiah. Bentuk penelitian kualitatif yang dipilih yakni studi kasus. Hamzah (2020: 3) berpendapat bahwa penelitian studi kasus tidak hanya menjawab pertanyaan penelitisn tentang apa (what) objek yang diteliti, tetapi secara komprehensif tentang bagaimana (how) dan mengapa (why) objek terjadi dan dapat dipandang sebagai kasus (memiliki pola dan unsur kesengajaan).

Posisi peneliti dalam penelitian 
kualitatif studi kasus ini adalah sebagai instrumen kunci. Hal tersebut sesuai dengan pernyataan Creswell (2018: 251) yang menyatakan bahwa penelitian kualitatif merupakan interpretatif, yang didalamnya peneliti terlibat dalam pengalaman yang berkelanjutan dan terus-menerus dengan para partisipan. Sukmadinata (2013: 114) menjelaskan bahwa pengumpulan dan analisis data penelitian kualitatif bersifat interaktif, berlangsung dalam lingkaran yang saling tumpang tindih. Teknik pengumpulan data dalam penelitian kualitatif oleh Mulyadi, Basuki, \& Prabowo (2019: 211) yakni dengan menggunakan observasi, wawancara, dan dokumen. Oleh karena itu, peneliti menggunakan teknik triangulasi dalam analisis datanya, yakni membandingkan berbagai temuan data melalui berbagai sumber yang berbeda dan teknik pengumpulan data yang diperoleh melalui observasi dengan cara peneliti melakukan catatan langsung saat kejadian, wawancara dengan narasumber terkait untuk memperoleh penjelasan, serta menganalisis dokumen yang hasilnya berupa deskripsi terkait isi dan kesimpulan peneliti.

Kajian khusus dalam penelitian ini adalah orientasi agama sebagai kurikulum tersembunyi yang tercermin melalui berbagai realitas kegiatan keagamaan yang dialami oleh peserta didik. Penelitian studi kasus ini bersifat tunggal terpancang, yaitu penelitian kualitatif yang sudah menentukan fokus penelitiannya berupa variabel utama atau inti yang akan dikaji berdasarkan pada tujuan dan minat peneliti. Tunggal berarti hanya ada satu lokasi penelitian, sedang terpancang artinya hanya pada tujuan kegiatan yang bersifat keagamaan.

\section{HASIL DAN PEMBAHASAN}

Nurhasanah (2020) menyatakan bahwa secara etimologi, hidden curriculum berasal dari bahasa asing yaitu bahasa inggris yang terdiri dari dua kata yaitu hidden dan curriculum. Hidden berarti tersembunyi atau terselubung dan curriculum berarti kurikulum.
Ketersembunyian kurikulum ini perlu disadari keberadaannya sehingga dapat dikendalikan serta memberikan manfaat positif bagi peserta didik. Yolanda \& Mudjito (2019) berpendapat bahwa kegiatan hidden curriculum peserta didik dapat membiasakan tingkah laku atau berperilaku sesuai dengan nilai-nilai dan norma yang berlaku. Oleh karena itu, proses pembentukan dan kegiatan yang merupakan kurikulum tersembunyi perlu dipahami oleh lembaga pendidikan.

Orientasi agama merupakan pendekatan ataupun pandangan seseorang dalam menjalankan keyakinannya. Tentunya, orientasi agama merupakan kurikulum tersembunyi karena mempengaruhi kegiatan yang akan dijalankan peserta didik. Orientasi agama akan menentukan nilai-nilai yang harus diajarkan ataupun ditanamkan kepada peserta didik sesuai dengan keyakinan yang dianut. Hal tersebut selaras dengan pendapat Sabriadi (2020) yang menjelaskan terkait aspek relatif tetap dari kurikulum tersembunyi adalah ideologi, keyakinan, nilai budaya masyarakat yang mempengaruhi sekolah termasuk menentukan jenis budaya yang patut dan tidak patut diwariskan kepada peserta didik.

Identifikasi keberadaan kurikulum tersembunyi dilakukan melalui pengamatan secara langsung terkait proses pembelajaran peserta didik. Oleh karena itu, perlu dipahami secara pasti terkait detil proses pembelajarannya. Sebelum pandemi covid-19, kegiatan pembelajaran peserta didik berpusat di sekolah sebagai lokasi utama. Namun, saat pandemi covid-19 berlangsung, kegiatan pembelajaran peserta didik berpusat diluar sekolah atau yang sering disebut sebagai kegiatan BDR (Belajar Dari Rumah).

SD Negeri sebagai subyek pada penelitian ini telah melakukan berbagai penyesuaian selama pandemi covid-19 berlangsung. Penyesuaian tersebut yakni dengan menghadirkan program pembelajaran secara daring dan luring. Daring atau dalam jaringan yakni program pembelajaran secara digital. Daring dilakukan melalui berbagai cara 
yakni online (melalui aplikasi Whatsapp, Youtube,Office Form) dan melalui siaran TVRI (program tayangan edukasi BDR). Luring atau luar jaringan dilakukan dengan cara kunjungan langsung ke rumah peserta didik secara individu maupun kelompok.

Guru wali kelas 6 melakukan pengembangan pembelajaran selama pandemi covid-19. Pengembangan tersebut berupa pembuatan agenda kegiatan harian yang akan diisi secara mandiri oleh peserta didik. Agenda kegiatan harian diperlukan karena kegiatan pembelajaran bersama guru hanya dapat berlangsung secara terbatas. Lembar agenda kegiatan harian tersebut akan disajikan melalui Gambar 1 berikut ini.

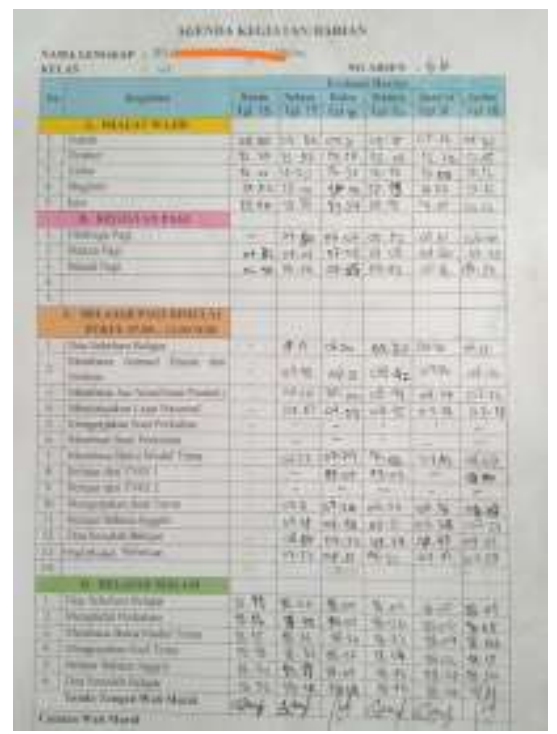

Gambar 1. Agenda Kegiatan Harian

Agenda kegiatan wajib diisi oleh peserta didik selama pembelajaran pada masa pandemi covid-19 berlangsung. Agenda kegiatan harian juga memuat berbagai kegiatan yang merupakan kurikulum tersembunyi. Berikut ini merupakan penjelasan proses pembentukan dan penyesuaian kurikulum tersembunyi melalui sudut pandang kegiatan keagamaan selama masa pandemi covid-19 berlangsung.

1. Proses Pembentukan Kurikulum Tersembunyi.

Kurikulum tersembunyi muncul dikarenakan lembaga pendidikan melakukan usaha lebih untuk memenuhi kebutuhan dan tujuan penyelenggaraan pendidikanya. Hal tersebut terjadi karena sekolah dituntut untuk terus mengembangkan berbagai program layanan pendidikan. Penelitian ini mengungkap bahwa pembentukan kurikulum tersembunyi di SD Negeri terkait melalui beberapa tahapan, yakni input, process, dan output.

Input merupakan tahapan yang mendasari terbentuknya kurikulum tersembunyi. Secara internal SD Negeri terkait memiliki visi yakni terwujudnya sekolah yang mengedepankan semangat disiplin, bersih, dan prestasi dengan dilandasi kesadaran serta tanggung jawab bersama, dengan salah satu misinya yakni pembinaan agama dan budi pekerti. Hasil wawancara dengan kepala sekolah juga diperoleh bahwa pembentukan karakter keagamaan tidak cukup bila hanya secara teori didalam kelas melalui penyampaian materi pelajaran agama. Secara eksternal pembentukan kurikulum tersembunyi SD juga dipengaruhi adanya tuntutan dari masyarakat akan kebutuhan layanan pendidikan yang lebih baik. Oleh karena itu, 
SD membentuk berbagai program layanan pendidikan, khususnya dari aspek keagamaan yakni berupa kurikulum tersembunyi. Mahali (2020) menyatakan Kurikulum tersembunyi dalam hal ini merupakan sesuatu yang menjadi misi tertentu yang hanya diketahui oleh seorang guru atau pengelola pendidikan.

$$
\text { Process merupakan tahapan }
$$

pembentukan kurikulum tersembunyi yang disengaja, termasuk dalam pelaksanaannya. Pembentukan kurikulum tersembunyi secara sengaja dilakukan dengan menghadirkan berbagai kegiatan yang diprogramkan diantaranya doa sebelum dan sesudah pelajaran, membaca Al-Quran, membaca asmaul husna, penjadwalan salat dhuha, salat dhuhur berjamaah, kultum setelah salat dhuhur, dan infaq rutin. Sementara kegiatan yang tidak diprogramkan tapi ditanamkan melalui pembiasaan yakni mengucapkan salam dan berpakaian rapi menutup aurat. Hal ini selaras dengan pernyataan Transinata (2017) yang menjelaskan terkait konsep kurikulum tersembunyi mengacu pada nilai-nilai yang tak terucapkan atau implisit, perilaku, dan normanorma yang ada di lingkungan pendidikan.

Output berkaitan dengan hasil akhir yakni tujuan tercapai. Tujuan dari pembentukan kurikulum tersembunyi yang bersifat keagamaan yakni terwujudnya peserta didik yang berakhlak baik dan berbudi luhur serta menciptakan lingkungan sekolah yang religius sehingga dapat membantu menunjang proses pembelajaran. Gunawan, et al (2018) menyatakan bahwa kurikulum tersembunyi menjadi faktor penting dalam proses pembentukan karakter.

2. Kegiatan Keagamaan Sebagai Kurikulum Tersembunyi.

Temuan penelitian ini mendapati bahwa kurikulum tersembunyi di SD sangat dipengaruhi oleh orientasi agama yang diyakini oleh para warga sekolah. Hasil kegiatan wawancara dengan kepala sekolah dan guru menunjukkan bahwa SD tersebut dari tahun ke tahun selalu memiliki peserta didik yang keseluruhannya beragama islam.
Lingkungan di sekitar SD terkait memang mayoritas memeluk agama islam. Tentunya orientasi kepercayaan beragama ini mempengaruhi layanan pendidikan yang diberikan oleh SD, khususnya berbagai pengembangan kegiatan yang disengaja maupun sudah menjadi kebiasaan bersama. Adapun berbagai kegiatan tersebut akan dibahas lebih mendetail melalui penjelasan berikut ini.

a. Doa sebelum dan sesudah pelajaran.

Doa sebelum dan sesudah pelajaran merupakan kegiatan yang wajib dilakukan oleh peserta didik. Kegiatan ini bertujuan untuk meminta kemudahan dalam memahami ilmu yang akan dipelajari. Kegiatan berdoa ini juga merupakan bentuk kedekatan peserta didik dengan Tuhannya. Kegiatan tersebut juga bermanfaat untuk memberikan ketenangan hati dan pikiran agar bisa lebih fokus dalam pembelajaran. Kegiatan berdoa sebelum dan sesudah pembelajaran sebelum pandemi covid-19 dilaksanakan di ruang kelas. Namun, saat pandemi covid-19 berlangsung, kegiatan tersebut dilakukan secara mandiri saat daring, dan dilakukan bersama guru saat luring yang kemudian dicatat dalam agenda kegiatan harian.

b. Membaca Al-Quran.

Al-Quran merupakan kitab suci umat beragama islam atau muslim. Tentunya, kewajiban bagi seorang muslim untuk membaca dan mempelajari isi Al-Quran. SD Negeri Terkait memiliki peserta didik dari tahun ke tahun yang keseluruhan beragam islam. Oleh karena itu, kebiasaan membaca Al-Quran setiap hari dilakukan setiap pagi selama 5-10 menit sebelum kegiatan pembelajaran dimulai. Kegiatan membaca Al-Quran ini merupakan salah satu bentuk variasi kegiatan gerakan literasi sekolah. Tujuan kegiatan tersebut adalah agar peserta didik mempelajari agama yang dianutnya lebih dalam dan sebagai wujud pembiasaan dalam taat beribadah. kegiatan membaca Al-Quran selama masa pandemi 
covid-19 berlangsung dilaksanakan secara mandiri oleh peserta didik. Kegiatan tersebut juga di catat dalam agenda kegiatan harian.

c. Membaca asmaul husna.

Asmaul husna merupakan nama-nama baik atau sebutan bagi Allah SWT yang merupakan Tuhan bagi umat muslim. Asmaul Husna sendiri berjumlah 99 dan masing-masing memiliki arti sekaligus makna yang baik. Kegiatan membaca asmaul husna dilakukan setiap setelah membaca Al-Quran di pagi hari sebelum pembelajaran dimulai dan setelah membaca Al-Quran. Kegiatan ini dilakukan dengan membaca kata arab sekaligus artinya sebanyak 5 nama. Hal tersebut dilakukan atas pertimbangan pembagian waktu pelaksanaan kegiatan gerakan literasi sekolah di pagi hari. Kegiatan membaca asmaul husna juga mengalami penyesuain selama pandemi covid-19 yakni dilaksanakan secara mandiri dan dicatat dalam lembar agenda kegiatan harian.

d. Penjadwalan salat dhuha.

Salat dhuha merupakan kegiatan ibadah umat muslim yang hukumnya sunah. Sunah dalam artian bila tidak dilaksanakan maka tidak mendapatkan dosa dan bila dilaksanakan mendapatkan pahala. Kegiatan salat dhuha dilakukan setiap istirahat pertama pukul 09.00 WIB dengan penjadwalan setiap kelasnya. Kelas 6 yang merupakan subyek penelitian ini mendapat jadwal salat dhuha setiap hari senin. Kegiatan ini bertujuan untuk membiasakan peserta didik dalam memanfaatkan waktu istirahatnya melalui kegiatan yang bersifat positif. Kegiatan salat dhuha tidak berlangsung selama masa pandemi covid19. Hal ini dikarenakan atas pertimbangan beban kegiatan yang dilaksanakan peserta didik secara mandiri agar tidak terlalu memberatkan.

e. Salat dhuhur berjamaah.

Salat dhuhur merupakan salah satu kegiatan ibadah yang hukumnya wajib bagi seorang muslim untuk mengerjakannya. Kegiatan salat dhuhur berjamaah ini dilaksanakan oleh kelas 3 sampai 6 secara rutin di masjid sekolah. Kebijakan ini diambil karena kelas 3-6 memiliki jam pulang siang antara jam 12.00 - 14.00 WIB. Kegiatan ini memiliki tujuan utama yakni agar para peserta didik taat dalam menjalankan ibadah wajibnya sebagai seorang muslim. Kegiatan salat dhuhur berjamaah ini pada pandemi covid19 tidak dapat berlangsung dikarenakan ketidakmungkinan untuk menyelenggarakan di lingkungan masjid sekolah. Oleh karena itu, penyesuaian yang dilakukan yakni menggantinya dengan kegiatan salat wajib secara mandiri dan dicatat dalam lembar agenda kegiatan harian.

f. Kultum setelah salat dhuhur.

Kultum merupakan kepanjangan dari kuliah tujuh menit. Kultum merupakan kegiatan dalam mendengarkan ceramah selama 7 menit berkaitan dengan agama. Kegiatan kultum ini dilaksanakan dengan menunjuk salah seorang peserta didik untuk memberikan ceramahnya. Penunjukan pengisi kultum atau penceramah dilaksanakan secara acak dan merata yang wajib bagi peserta didik kelas 5-6. Kegiatan kultum ditiadakan dan tidak ada penyesuaian selama pandemi covid-19 dengan pertimbangan beban kegiatan peserta didik agar tidak terlalu berat.

g. Infaq rutin.

Infaq merupakan kegiatan mengeluarkan harta, biasanya berupa uang secara sukarela. Kegiatan infaq dilaksanakan setiap hari selasa dan jumat. Peserta didik diberikan kebebasan untuk jumlah berapapun uangnya untuk diinfaqkan, tentunya diberikan kebebasan pula bila tidak berinfaq. Kegiatan ini bertujuan untuk menumbuhkan sikap peduli pada peserta didik. Uang hasil infaq akan dimanfaatkan dalam berbagai kegiatan, misalkan saja pada kegiatan sosial seperti memberi santunan saat menjenguk peserta didik yang 
sakit dan memberi santunan pada peserta didik yang kurang dalam segi ekonominya. Kegiatan infaq ini mengalami penyesuaian selama pandemi covid-19, yakni dilakukan 2 kali dalam seminggu dan saat pembelajaran secara luring.

h. Mengucapkan salam.

Kalimat ucapan salam bagi umat muslim adalah "Assalamu'alaikum wa Rohmatullohi wa Barokatuh" dengan jawaban "Wa'alaikumussalam wa Rohmatullohi wa Barokatuh". Tentunya, karena seluruh peserta didik beragama islam, maka pengucapan tersebut dibiasakan. Pengucapan salam ini dibiasakan terutama didalam kelas yakni setelah berdoa bersama sebelum dan sesudah pembelajaran antara peserta didik dan guru. Sementara diluar kelas, pengucapan salam tersebut dilaksanakan bila saling berpapasan satu dengan lain, khususnya bagi guru yang aktif dalam memberikan teladan. Selama pandemi covid-19 kegiatan mengucapkan salam tetap dibudayakan khususnya saat pembelajaran secara luring.

i. Berseragam rapi menutup aurat.

Berseragam rapi pada pembahasan ini yakni dipengaruhi anjuran berpakaian menurut agama islam. Kesehariannya, peserta didik putri berseragam memakai jilbab, baju lengan panjang, dan rok panjang, sedangkan peserta didik putra memakai celana panjang. Cara berpakaian tersebut bukan karena aturan sekolah, namun dikarenakan pengaruh dari anjuran agama islam tersebut. Hal tersebut terbukti melalui analisis dokumen tata tertib sekolah yang tidak ditemukan secara spesifik cara berpakaian tersebut. Tentunya hal ini ditindaklanjuti oleh peneliti melalui wawancara. Hasil wawancara dengan kepala sekolah dan guru diperoleh informasi bahwa cara berpakaian tersebut diawali dari mayoritas atau banyaknya peserta didik yang berpakaian seperti itu, kemudian peserta didik yang lain mengikuti. Secara tidak langsung, peserta didik barupun mengikuti cara berpakaian tersebut, sehingga sudah membudaya dengan sendirinya. Kegiatan memakai seragam saat pandemi covid-19 mengalami penyesuaian, yakni peserta didik tetap diwajibkan memakai seragam meskipun kegiatan secara BDR. Pakaian seragam wajib dipakai sampai pukul 12.00 WIB dengan pertimbangan agar peserta didik tetap disiplin serta menanamkan pola pikir bahwa seragam tersebut merupakan identitas sebagai seorang pelajar.

\section{SIMPULAN DAN REKOMENDASI}

Kegiatan keagamaan sebagai kurikulum tersembunyi di salah satu SD Kecamatan Kalijambe Kabupaten Sragen dipengaruhi oleh orientasi agama islam. Hal tersebut dikarenakan selama bertahun-tahun anggota warga sekolah SD seluruhnya memeluk agama islam. Kegiatan keagamaan yang mengalami penyesuaian selama masa pandemi covid-19 yakni doa sebelum dan sesudah belajar, membaca Al-Quran, membaca asmaul husna, salat dhuhur berjamaah, infaq rutin, mengucapkan salam, dan berseragam rapi. Kegiatan keagamaan yang tidak terlaksana selama masa pandemi yakni penjadwalan shalat dhuha dan kultum setelah salat dhuhur.

Kegiatan keagamaan di SD Negeri terkait sudah sesuai dengan orientasi agama yang dipeluk oleh anggotanya. Kegiatan keagamaan tersebut perlu dievaluasi secara rinci, khususnya berkaitan dengan dampak terhadap peserta didik. Hal tersebut penting agar kegiatan keagamaan sebagai kurikulum tersembunyi dapat berdampak positif. Kepastian dampak positif dari kegiatan keagamaan tentunya akan membentuk karakter religius peserta didik.

DAFTAR PUSTAKA

Ali., \& Aisyah, M. (2018). Pendidikan Karakter: Konsep dan 
Implementasinya.

Jakarta:

Prenadamedia Group Divisi Kencana.

Caswita. (2013). The Hidden Curriculum: Studi Pembelajaran PAI di Sekolah. Yogyakarta: Leutikaprio.

Creswell, J. W. (2018). Research Design: Pendekatan Metode Kualitatif, Kuantitatif, dan Campuran. Yogyakarta: Pustaka Pelajar.

Gunawan, I., Kusumaningrum, D. E., Triwiyanto, T., Zulkarnain, W., \& Nurabadi, A. (2018). Pengaruh Kurikulum Tersembunyi terhadap Motivasi Diri Mahasiswa. In Prosiding Seminar Nasional Pendidikan, Tema: Mendidik Cerdas Generasi Digital, Fakultas Ilmu Pendidikan Universitas Negeri Malang, 4, 90-97. http://anzwild.com/wpcontent/uploads/2018/12/sn18.pdf

Hamalik, O. (2017). Dasar-dasar Pengembangan Kurikulum. Bandung: PT Remaja Rosdakarya.

Hamzah, A, (2020). Metode Penelitian Studi Kasus Single Case, Instrumental Case, Multicase \& Multisite. Malang: Literasi Nusantara.

Mahali, A. (2020). Kurikulum Tersembunyi dalam Pembelajaran PAI. Prosiding Nasional, 3, 181-188. https://prosiding.iainkediri.ac.id/index. php/pascasarjana/article/view/50/40

Moleong, L. J. (2018). Metodologi penelitian kualitatif. Bandung: PT Remaja Rosdakarya.

Mulyadi, S., Basuki, H., \& Prabowo, H. (2019). Metode Penelitian Kualitatif dan Mixed Method Perspektif yang Terbaru untuk Ilmu-ilmu Sosial, Kemanusiaan, dan Budaya. Jakarta: Raja Grafindo Persada.

Mustaqim, M. (2018). Konsep Pendidikan Good Netizen Melalui Kurikulum Tersembunyi. Jurnal Perspektif, 2(1), 80-92. http://dx.doi.org/10.15575/jp.v2i1.15
Nisa, K. (2009). Hidden Curriculum: Upaya Peningkatan Kecerdasan Spiritual Siswa. Lentera Pendidikan: Jurnal Ilmu Tarbiyah dan Keguruan, 12(1), 72-86. https://doi.org/10.24252/lp.2009v12n1 a6

Noor, R. M. (2012). The Hidden Curriculum Membangun Karakter Melalui Kegiatan Ekstrakurikuler. Yogyakarta: Insan Madani.

Nurhasanah, N. (2020). Pelaksanaan Hidden Curriculum (Kurikulum Tersembunyi) Dalam Membentuk Karakter Siswa Di Smp Slwashliyah 5 Hamparan Perak. ANSIRU PAI: Pengembangan Profesi Guru Pendidikan Agama Islam, 4(2), 80-92. http://dx.doi.org/10.30821/ansiru.v4i2. 8127

Prasetya, R., Febriyanto, B., \& Ryanto, A. (2020). Implementasi Hidden Curicculum Dalam Pembentukan Karakter Peserta Didik. PROCEEDING UMSURABAYA. http://journal.umsurabaya.ac.id/index.php/Pro/article/do wnload/4868/2809

Rahmawati, F., Afifulloh, M., \& Sulistiono, M. (2020). Budaya Religius: Implikasinya Dalam Meningkatkan Karakter Keagamaan Siswa Di MIN Kota Malang. Elementeris: Jurnal Ilmiah Pendidikan Dasar Islam, 2(2), 22-35. http://dx.doi.org/10.33474/elementeris. v2i2.8685

Sabriadi, H. R. (2020). Manifestasi Hidden Curriculum Dalam Pendidikan Agama Islam. Ekspose: Jurnal Penelitian Hukum dan Pendidikan, 19(1), 947954.

http://dx.doi.org/10.30863/ekspose.v1i 1.769

Setiawan, R. (2017). Pembangunan Nilai Demokrasi dan Nasionalisme sebagai Kurikulum Tersembunyi di SMAN CMBBS. Hermeneutika: Jurnal 


\section{PRIMARY: JURNAL PENDIDIKAN GURU SEKOLAH DASAR \\ VOLUME 10 NOMOR 3 JUNI 2021 \\ ISSN : 2303-1514 | E-ISSN : 2598-5949 \\ DOI : http://dx.doi.org/10.33578/jpfkip.v10i3.8293 \\ https://primary.ejournal.unri.ac.id/index.php/JPFKIP}

Hermeneutika, 3(1), 10-20. http://dx.doi.org/10.30870/hermeneuti ka.v3i1.3010

Sukmadinata, N. S. (2013). Metode Penelitian Pendidikan. Bandung: PT Remaja Rosdakarya.

Transinata, T. (2018). Integrasi Pendidikan Cinta Tanah Air dalam Kurikulum Tersembunyi Berbasis Karakter Kebangsaan. PHILANTHROPY: Journal of Psychology, 1(1), 47-64. http://dx.doi.org/10.26623/philanthrop y.v1i1.679

Yolanda, P. (2019). Implementasi Program Pendidikan Karakter Berbasis Hidden Curriculum di MI Muhammadiyah 1 Pare Kediri. Inspirasi Manajemen Pendidikan, 7(1), 1-35. https://jurnal.unesa.ac.id/index.php/ins pirasi-manajemenpendidikan/article/view/27809/25445 